\title{
Learning Method of Arabic Among People with Disability of Blind
}

\author{
Ridwan Effendi \\ Arabic Language Department \\ UIN Syarif Hidayatullah \\ Jakarta, Indonesia \\ E-mail: effendiridwan40@gmail.com
}

\begin{abstract}
Problematic learning of foreign languages including Arabic language in Indonesia has two obstacles, linguistic and non linguistic. Linguistically usually includes: grammar, pronunciation, vocabulary and so on. While in non linguistic usually concerned on motivation, psychological, infrastructure, and so on.
\end{abstract}

The author sees that the two obstacles can be overcome in various ways, including through the application of appropriate methods. Arabic material that is difficult can become easier through the method approach applied in language learning. This method had been applied by the author to friends with disabilities who want to learn Arabic language.

Various studies and researchs have been conducted to determine the effectiveness and success of a method used in language learning. Choice of the appropriate methods from many available methods is the most important thing to consider by language teachers. Therefore, it needs carefulness of the teachers in choosing the method to be used. Learning methods should be adjusted to the conditions of learning objects or learners. One method may be suitable for use in one place and state, but in other places and conditions the method is unsuitable to be used.

As in this research, the authors taught Arabic for the blind disability of 20 people at Wyataguna Bandung by applying effective methods through certain techniques. This method is expected to have a positive impact on their Arabic speaking skills. Thus, the emphasis on mastery of language learning methods is expected to accelerate the increase of Arabic speaking ability for the blind.

\section{INTRODUCTION}

Antonio Quaetraro and Mario Paiano wrote New Ways of Language Learning for Blind or Visually Impard Children and Teenagers at the 3rd International Conference of ICT for Language Learning in Italy. He presented English learning through ELLVIS program (English Language Learning Program for Visually Impaired Students).[1] Ellvis is a new language learning technology based on the interaction between machines and humans using heptik and kinesthetic. Ellvis involves variations in manual abilities by relying on the coordination between hearing and hands, so the learning process is more efficient. Ellvis program not only relies on passive hearing, but more on the physical interaction between teachers and learners. Ellvis program is emphasized on the ability of hearing and hand grip skills in operationalize the program. Thus, the blinds become trained in hearing and touching, especially in English.
According to Abdulloh Coskun in 2013 in Turkey. Ia offers T3 method in learning English, which is talking, tactile, and technology.[2]

Meanwhile, according to Moonica Lovi also wrote in her thesis entitled Aspects of Teaching and Learning English as A Foreign Language in the Case of Blind and Visually Impaired Learners.[3] She expressed two main aspects in learning are closely related to sight. First, the aspects relating to the format of learning materials. Second, methods and techniques for students with visual impairment who learn a foreign language. She state the importance of the availability of teaching materials that are easily accessible by learners and easy to implement using other teaching methods and activities. Thus it will not burden the teachers in the process of learning the language with learners who have visual limitations.

As for this research, the author tries to apply arabic learning pattern which emphasize on methodology aspect and technique. Language materials are taught by the approach of certain sounds and Arabic acronyms into Indonesian language to facilitate the understanding of Arabic. The purpose in this research are:

1. Providing information as well as expand the knowledge about the method of learning Arabic for the blind.

2. Providing clear picture of the application of Arabic methods, techniques and learning materials for the blind.

3. Giving early input which needs to be followed up by managers of educational institutions and other researchers related to the application of methods of learning Arabic for the blind.

\section{METHODS}

This paper use two sources, there are primary and secondary sources. Primary sources consist of instructors / teachers and blind participants who follow Arabic learning and Arabic language materials. Besides the fact of language in the field during learninga activity. Meanwhile secondary source related to the language jounals and language linguistics books.[4]

The method used in this study through the approach of psychology and sociology of language education. Psychology approach in language education is related to internal factors such as talent, interest, motivation, and 
competence of language learners. The sociology approach is about the external aspects of the learner, such as environment, teachers, teaching materials, and social interaction in language learning.[5] This research is qualitative because this research produces descriptive data in the form of words or writings of people and behavior that can be observed.

\section{RESULT AND DISCUSSION}

Based on the findings of the field, when the authors looked at the application of Arabic methods for the blind, finding some methods relevant to the blindness of even those methods proved to improve the ability to speak Arabic. The methods are audio-lingual and communicative methods. Both methods are able to encourage the blind can absorb the materials taught by the instructor / teacher in the end can produce a conducive language learning.

\section{A. Audiolingual Arabic Learning Method for the Blind}

Instructors in Arabic learning use audiolingual method to be the first method. This method is chosen as the early foundation for the next lesson. This method was chosen with the assumption that the majority of Arabic language learners who are blind can hear well. Instructors present training materials through audiolingual methods with varied techniques. The audiolingual method itself is a method that relies on auditory functions. Implementation of audiolingual methods for the blind is much directed to the ability to hear or often hear specific vocabulary in the process of language learning. Thus the blind people who are learning Arabic language are used to hearing and will produce a product of the ability to speak using phrases in Arabic.[6]

The process of teaching language apply audiolingual methods must meet several principles. In this model, the blind people should listen optimally and speak. Grammar is presented in the form of sentence patterns or dialogue with the topic of everyday situations. Drill must follow the order of operan conditioning and there should be a reward. All the elements of grammar should be presented, from the easiest to the most difficult.

As it is known that a blind person has visual impairment, but has no hearing disorder. Many researchers believe that the language ability of the blind child is similar to the ability of the ordinary child in general. The main difference lies in how they learn to receive information. Blind people for example receive a lot of information through auditory and tactile, while a ordinary person can maximize all five senses. Therefore the training of this method for the blind start from the belief that language can be obtained through a recurrent habituation or drill (تدريبات). The purpose of this practice of habituation is that the blindcan master the pattern of sentences that deliberately taught automatically.[7]

This audiolingual method on the practical level has a derivative of some learning techniques. An example is the technique of drilling, it is repetition of sentences or certain expressions such as greeting, leading the prayer of learning, ending learning and some form of command sentence commonly used in the classroom. This is one of the advantages of audiolingual methods. The use of audiolingual methods in language learning, can make blind students skilled make sentence patterns as they are drilled in addition they have a good memory. Meanwhile the student responds to stimulation provided by the instructor or instructor countinously.

Another learning technique that is derived from the audiolingual method is the technique of singing. Singing techniques can be used in certain materials, such as materials to recognize ism ḍamîr and memorize vocabulary fi'l mâḍi and fi'l muḍari'. Technique singing is considered as a derivative of audiolingual methods so being applied in learning more listening and following songs taught by the instructor. Another technique is a word game of guessing techniques. The material introduced in word guess games is the vocabulary related to the sense of hearing, the sense of taste, the sense of touch, and the sense of sight.

\section{B. Communicative Arabic Learning Method for the Blind}

One of the major competencies in language learning is speaking. The ability to speak can be obtained through the process of habituation. While vision impairment experienced by a person does not inhibit the ability of verbal, if he gets a lot of stimulation from the surrounding environment to speak. This stimulation can be obtained by the blind people who follow the learning of Arabic language from the instructor. Interactions that occur between them during the learning is an effective medium to improve their verbal skills.

Not only that, people who suffer from vision problems can even sharpen their ability to master several foreign languages at once, including Arabic. This is evidenced by a blind Russian poet who mastered ten languages other than Russian. However, to have such ability the need for support from various aspects. One aspect that is very influential on the ability to learn the language is the accuracy of learning methods used.

Based on the analysis of the needs of Arab language learners, it is known that about eighteen of the twenty arab language learners claimed to require speaking skills as a key aspect. Nearly $90 \%$ of the learners acknowledge that the methods they have found from learning elsewhere focus more on sentence structure or grammar only. They think that the lessons they have learned elsewhere tend to be bored. The importance of this method of learning is greatly emphasized by Mahmud Yunus with his expression : al-t\{ari@qah ahammu min al-ma>ddah, which means a method or way more important than the material itself. Any material if delivered with the correct method, will be well received.

Knowing such a reality, the author tries to apply the communicative method as a solution to the existing conditions. According to Richards some of the learning objectives with communicative methods are: first, 
knowing the function and purpose of the language. Second, knowing when the use of formal and informal language, written and spoken is used. Third, knowing how to make and understand text differences such as narrative text, report, interview, and conversation. Fourth, knowing how communication can be created without being limited by the knowledge of the language itself. So it is not limited by the rules of language.[8] Communicative methods is a method that put forward the ability to listen and speak both ways. In this case the communicative method successfully stimulates the willingness and ability to speak the learners correctly and purposefully or commonly known cohesion and coherence. The willingness and confidence of blind learners who at first get experienced mental block finally helped by the presentation of the material through communicative methods applied by the instructor / instructor.[9]

Communicative methods have several derivative techniques. Derivative techniques of communicative methods include practical dialogue techniques and learning techniques based on collaborative learning approach. Blind learners of arabic languages asked to do practical dialogue asked to practice a simple dialogue of question and answer with friends. While the technique of collaborative learning is a language learning technique that puts forward the pattern of discussion. Technique is done among peers who experience the gap ability in understanding the material. The implementation of this technique is guided by one participant of other blind learner who has already mastered the material already taught. In the technique of collaborative learning, blind learners can freely ask their other friends. Another blind learner who acts as a facilitator by reviewing the material already taught by the instructor / instructor.

Communicative method is a method derived from the assumption that every human being has an innate ability called the "acquisition language" (language acquisition device).[10] Therefore, the language skill is creative and more determined by internal factors. So the relevance and effectiveness of habituation activities with the model stimulus-response-enforcement exercise. The teaching of Arabic with the communication method, known in the 1940 s and dominating the field of foreign language teaching until the late 1960 s is part of the principle of this approach. In 1957 M Noam Chomsky announced his revolution against the thinking of structuralist behaviorists. He attacked the structuralist behaviorists because he regarded languages only formally and externally.

Chomsky concerns with language competence, not just limited to external discussions. He explained that language learning with communication methods, does not realize the purpose of communication for the language. He links the ideal speaker's knowledge to the grammatical structure of language. He says that linguistic theory is concerned with the ideal speaker-listener.

Another case with Chomsky's theory, the method of learning Arabic for blind people using a communication approach is even more effective when applied to blind students. The combination of audiolingual and communicative methods produces a harmonious alloy in which they are able to learn basic arabic languages as simple way. This is because the blind learners rely on hearing then responded in the form of sound and in use into the form of communication with Arabic language with each other. Thus, Chomsky's argument against structuralist behaviorists is not fundamental. This is because the condition of blind learners is more in need of habituation through hearing response.

However, other linguists see that the language competence that Chomsky and his followers call basically is nothing but grammatical competence. These competencies are limited to the knowledge of language rules only. Therefore, they often call upon the terms they terminate with communicative competence. This competence includes knowledge of the origin of speech and its methods and pay attetion to the characteristics of people who to talk to. For example, sentences for requests, apologies, thanksgiving, invite, etc. The important thing that cannot be left behind is knowing the rules of language and vocabulary. So that, the meaning of language competence is to know the rules and systems of the language, both syntactic, morphological, and phonetic systems.

Thus the method of communication seen from the relevance of communicative methods in accordance with the needs of blind learners, both experiencing barriers to learning and who do not experience barriers to learning. This method is then derived in practical dialogue techniques and singing techniques. When viewed from the characteristics of communicative methods, learning grammar is not as the main factor of learning objectives. The principle of this method also believes that mistakes in the language is something reasonable. This method also connects between two skills of language proficiency, namely listening and speaking.

\section{CONCLUSIONS}

Based on the description above the conclusion of the writing of this research are as follows:

The first is related to the Arabic learning method for the blind. A method is considered effective when the expected goal can be achieved by the application of the such method. The timeliness and the results also determine the effectiveness of a method. The results showed that there are two effective methods in the learning method of Arabic for the blind. Effective methods are: audiolingual learning methods which emphasize the ability of hearing, communicative learning methods which emphasize the ability of speech. Thus both methods as one way to improve the ability of foreign languages including Arabic for the blind.

\section{REFERENCES}

[1] A. Quaetraro and M. Paiano, "New Ways of Language Learning for Blind or Visually Impard Children and Teenagers," presented 
at the The 3rd International Conference of ICT for Language Learning, Italy.

[2] C. Abdullah, "English language teaching for the visually impaired learners: training non native english teachers International J. Social Science dan education,” 2013.

[3] M. Lovi, "Aspects of Teaching and Learning English as A Foreign Language in The Case of Blind and Visually Impaired Learners in Estonia University of Tartu," p. 5.

[4] L. J. Moleong, Metodologi Penelitian Kualitatif, 16th ed. Bandung: Remaja Rosdakarya, 2002.

[5] A. Ahmad and W. Supiyono, Psikologi Belajar. Jakarta: PT Rineka Cipta, 1991.

[6] A. F. Effendy, Metodologi Pengajaran Bahasa Arab. Yogyakarta: Miykat, 2009.

[7] Y. Abidin, Perspektif dan Prinsip-Prinsip Pembelajaran Bahasa. Tasikmalaya: HZAA Press, 2006.

[8] L. Richards, Communicative Language Teaching Today. Cambridge: Cambridge University Press, 2006.

[9] J. McLeod and K. von Treuer, "Towards a Cohesive Theory of Cohesion," Int. J. Bus. Soc. Res. IJBSR, vol. 3, no. 12, Desember 2013.

[10] M. Johnson, A Philosophy of Second Language Acquisition. London: Yale University Press, 2004. 